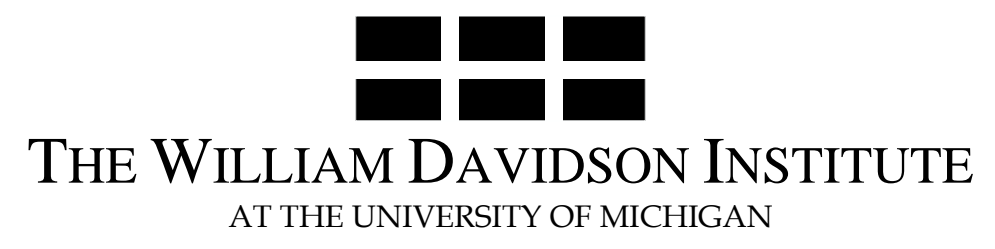

AT THE UNIVERSITY OF MICHIGAN

\title{
THE COST STRUCTURE OF MICROFINANCE INSTITUTIONS IN EASTERN EUROPE AND CENTRAL ASIA
}

By: Valentina Hartarska, Steven B. Caudill and Daniel M. Gropper

William Davidson Institute Working Paper Number 809

January 2006 


\title{
THE COST STRUCTURE OF MICROFINANCE INSTITUTIONS IN EASTERN EUROPE AND CENTRAL ASIA
}

January 18, 2006

\author{
Valentina Hartarska \\ Department of Agricultural Economics and Rural Sociology \\ 210 Comer Hall \\ Auburn University \\ Auburn, Al 36830 \\ Phone: 334-844-5666 \\ Email: Hartarska@ auburn.edu \\ Steven B. Caudill \\ Department of Economics \\ Auburn University, AL 36830 \\ Fax (334) 844-4615 \\ Email: scaudill@business.auburn.edu \\ Daniel M. Gropper \\ Department of Economics \\ Auburn University, AL 36830 \\ Fax (334) 844-4615 \\ Email: groppdm@auburn.edu
}

\begin{abstract}
Microfinance institutions are important, particularly in developing countries, because they expand the frontier of financial intermediation by providing loans to those traditionally excluded from formal financial markets. This paper presents the first systematic statistical examination of the performance of MFIs operating in Eastern Europe and Central Asia. A cost function is estimated for MFIs in the region from 1999-2004. First, the presence of subsidies is found to be associated with higher MFI costs. When output is measured as the number of loans made, we find that MFIs become more efficient over time and that MFIs involved in the provision of group loans and loans to women have lower costs. However, when output is measured as volume of loans rather than their number, this last finding is reversed. This may be due to the fact that such loans are smaller in size; thus for a given volume more loans must be made.
\end{abstract}

JEL: G200, G210, O160

Keywords: Eastern Europe, banking, microfinance, efficiency 


\section{Introduction}

Microfinance institutions are important, particularly in developing countries, because they expand the frontier of financial intermediation by providing loans to those traditionally excluded from the formal financial markets. The contribution of microfinance institutions (MFIs) to poverty alleviation has attracted significant attention in recent years. For example, the United Nations declared 2005 to be the International Year of Microcredit. Although usually small, MFIs control significant resources and serve significant numbers of borrowers. For example, in Eastern Europe and Central Asia (ECA) alone, these organizations have an asset base of about $\$ 1$ billion and serve about 500,000 active borrowers (Foster, Green, and Pytkowska, 2004).

Despite the growing importance of MFIs there have been no studies of MFI performance in the ECA region. While there has been a substantial prior literature on the cost structure of European banks (see, for example, Altunbas, Gardener, Molyneux, and Moore 2001; Altunbas and Molyneaux, 1996; Pastor, 2002; and Pastor, Perez, and Quesada, 1997) there have been only a few recent systematic studies of bank performance in the ECA region (Fries and Tasci, 2005; Hasan and Marton, 2003; and Bonin, Hasan, and Wachtel, 2005a, 2005b).

There is no systematic empirical work to date on the performance of MFIs, but there have been a few empirical studies in the related areas of relationship lending and community banking (see, for example, Berger and Udell, 1995; Berger, Hasan, and Klapper 2004; Berger, Klapper, Miller, and Udell, 2003; and Berger and Udell, 2002).

This paper adds to the literature by presenting the first systematic statistical examination of the performance of MFIs operating in Eastern Europe and Central Asia. Using high-quality data for a sample of MFIs from the region from 1999 to 2004, we estimate a cost function, incorporating characteristics which the literature suggests are likely to influence productivity but whose impact on MFIs in the ECA region has not been empirically estimated. For example, theoretical work suggests that group lending methodology decreases the costs of serving marginal clientele by mitigating problems of adverse selection (Ghatak 1999; Armendariz de Aghion and Collier, 2000) and moral hazard (Stiglitz, 1990; Laffont and Rey, 2003; Rai and Sjostrom, 2004). The empirical evidence for non-ECA MFIs shows that group lending is associated with higher repayment rates (Gomez and Santor, 2003). Armendariz de Aghion and Morduch (2000) argue, however, that individual lending contracts with dynamic incentives may 
be more cost-effective in countries in the ECA region. One goal of this paper is to provide empirical evidence on the issue of the relative costs of group lending.

To fulfill their poverty alleviation mission MFIs often target women because the majority of the poor are female. Because women have less access to capital, the return to capital may be, on average, higher than for men. Therefore, if capital is not fully fungible within the family, endowing women with capital may be growth-enhancing. Moreover, the limited labor mobility of women can decrease monitoring costs and reduce the incidence of strategic default. To date, empirical studies have not focused on the cost consequences of targeted lending to women in ECA region; this paper provides the first evidence of the impact of this practice on the cost structure of MFIs.

Another unique aspect of MFI operations is the presence of subsidies. Although the ultimate goal of microfinance institutions is to become financially self-sustainable, in practice all receive direct and indirect subsidies. The empirical impact of these subsidies on efficiency is not well understood (Armendariz de Aghion and Morduch, 2005). We present empirical evidence on how subsidies affect MFI productivity.

To examine and measure these various effects, we estimate three cost functions, each using different measures of output. Our first formulation uses the number of loans as an output measure, which is most consistent with the objective functions of these institutions. The second formulation uses volume of loans as an output measure. Our third formulation combines both the number and volume of loans as outputs. Our most consistent finding across specifications is that the presence of subsidies is associated with higher MFI costs. This result is consistent across all three output specifications and across several measures of subsidy. Our other findings depend on the particular output measure used. When output is measured as the number of loans, we find that MFIs become more efficient over time. With output measured as the number of loans we also find that MFIs involved in the provision of group loans and loans to women have lower costs. However, when output is measured as the total volume of loans, this last finding is reversed; MFIs involved in the provision of group loans and loans to women have higher than average costs. This may be due to the fact that group loans and loans to women are typically small, so that for a given volume of loans, a greater percentage of loans of these types would indicate more transactions and thus higher costs. 


\section{Microfinance Institutions}

Microfinance has been defined as "a collection of banking practices built around providing small loans (typically without collateral) and accepting tiny savings deposits" (Armendariz de Aghion and Morduch, 2005, p.1). Microfinance institutions provide financial services to the entrepreneurial poor who generally do not have access to traditional banking services. MFIs pursue a double bottom line of outreach and sustainability. On the one hand, MFIs fulfill an outreach mission by providing financial services to the poor. On the other hand, MFIs must operate like other financial institutions, lending to creditworthy clients and earning positive returns on their loan portfolios in order to sustain and expand their operations (sustainability). Because sustainability is an important goal of these organizations, we assume that MFIs strive to minimize costs of operation for any given level of operations.

Since poor customers generally have no credit history and little collateral, MFIs must use innovative lending practices to reduce risks associated with asymmetric information between lender and borrower. In fact, several studies have focused on understanding the mechanisms of lending practices such as group loans, a type of joint-liability loan, whereby the MFI delegates screening, monitoring, and contract enforcement costs to a group, and individual uncollateralized loans, whereby repayment is "secured" with a promise of access to larger loans in the future conditional on current loan repayment (Conning, 1999; Navajas et al., 2000). Other studies have focused on the impact that MFIs have on borrowers (Brau and Woller, 2004).

One way in which MFIs differ greatly from other financial institutions is that many aspects of MFI operations are characterized by subsidies. For example, the MFI equity base used to begin operations is typically contributed by an international donor. These donors include governments in developed countries, international organizations such as the World Bank, or intermediaries and international networks such as Opportunity International and FINCA International. If additional funds are required, donors may offer outright grants or loans at either subsidized or commercial rates, with the recent trend toward providing loans rather than grants.

In addition, MFIs may receive a variety of in-kind transfers and subsidies in the form of technical assistance and/or free physical capital. These subsidies affect the prices of labor and capital. In-kind subsidies can come in the form of outside funds for salaries of senior management or outside funds for personnel training. Subsidies of this kind are provided via technical assistance contracts paid for by either the Technical Assistance (TA) agency or a 
donor. In addition to these subsidies, local governments and TA agencies may provide cars, buildings, or other facilities to MFIs.

\section{Microfinance in the ECA Region}

At the beginning of the transition period, banks naturally focused on lending to larger and state-owned enterprises. Soon there were severe banking crises in almost every transition country. Two factors contributed to these crises. One factor was lax bank licensing policies. A second factor was the failure of banks to impose hard budget constraints because they correctly assumed that the government would bail them (Perotti, 1998). The lingering consequence of these bank crises is the present overregulation of the sector which makes provision of financial services to the poor even more difficult

MFIs emerged as one of the efforts to fill the gap in the financial services industry. In early transition, there was considerable interest in providing credit to Small ( $<100$ employees) and Medium (<500 employees) Enterprises (SMEs) but not to micro-entrepreneurs and selfemployed individuals. For example, in the first report on the state of microcredit in the region, the OECD indicated that out of the 20 SME programs operating in Poland, the Czech Republic, and Hungary only four reached microenterprises with small amounts of credit and three included microenterprises as part of their portfolio (Microcredit in Transitional Economies, OECD, 1996).

The first microfinance initiatives date back to 1992. Initially, large microfinance networks such as Opportunity International, CARE International, FINCA, and religious charities such as Catholic Relief sent missions to various countries to start microfinance activities. Some of these initiatives later grew into independent institutions. In addition, international donors such as the World Bank, United States Agency for International Development (USAID), and The German Development Agency (GTZ) provided grants and technical expertise resulting in the creation of new microfinance institutions.

In the past decade international donors increasingly prefer loans to grants for the establishment of microfinance activity. In fact, many of the loans to MFIs in Eastern Europe and Central Asia are simply commercial bank loans at the market rate of interest. As a consequence, the relatively young MFIs in Eastern Europe and Central Asia, relying more heavily on loans than grants, perhaps did not develop a subsidy-dependent culture. MFIs in this region operated 
in a unique environment unlike that of MFIs in other developing countries. These differences are manifested in the customers served, the products offered, and the funding sources available.

MFI Clients and Services. Microfinance initiatives in Eastern Europe and Central Asia emerged in an environment with considerable suspicion of and inexperience with entrepreneurship as well as lack of experience with charity and financial services. The widespread mistrust of the entrepreneur gave rise to a tendency on the part of government to overregulate entrepreneurial activity rather than create an enabling environment. For MFIs entering the market this meant that there were additional challenges because their clients faced not only financing constraints but also significant institutional constraints. These disadvantages were partially offset by the higher educational and skill levels of displaced workers in the ECA region seeking to become entrepreneurs.

MFIs in the region serve a wide range of clients but cater mostly to the poor and especially poor women. Foster, Green, and Pytkowska (2003) report that at the one end of the spectrum of MFI clients are women displaced or widowed by wars who require smaller loans (less than $\$ 1,000$ ) and for whom group loans may be appropriate. At the other end of the MFI spectrum are loans of up to $\$ 2,500$ offered to established microenterprises typically employing one or two people (such as mechanics, hairdressers and in some cases even doctors and dentists). On rare occasions the larger microenterprises take loans in the $\$ 5,000-\$ 10,000$ range.

MFIs in the ECA region have adapted their traditional lending technologies and management practices to accommodate the challenges of the environment and to take advantage of the opportunities that countries in the ECA region offer (Hartarska, 2005). For example, even MFIs that exclusively provide group loans such as FINCA International, introduced innovative individual lending techniques more appropriate to the new type of clients (Armendariz de Aghion and Morduch, 2000).

Compared to MFIs in other world regions, MFIs in Eastern Europe and Central Asia are among the youngest in the microfinance industry but already have showed financial results that are among the best in the industry (Benchmarking Microfinance in Eastern Europe and Central Asia, Microfinance Center, 2004). For example, The Microbanking Bulletin No 9 shows that in 2003 the average MFI in the ECA region was 5 years old, and had gross portfolio yield of 35 percent (in real terms), and operational self-sustainability of 131 percent, while the average MFI 
in the industry was 9 years old and had portfolio yield of 29 and operational self-sustainability of 123 percent.

Microfinance services in the ECA region are offered by four groups of organizations: 1) Non-governmental organizations (NGOs) or financial companies exclusively devoted to microfinance; 2) microfinance banks, which are chartered commercial banks devoted to microfinance services; 3) commercial banks which offer some microloans usually through a separate unit within the bank dedicated to MFI activities (called downscaling); and 4) Credit Unions.

Only ten credit unions are included in the analysis because most credit unions are not heavily involved in microfinance activities. Commercial bank departments engaged in microfinance but not operating as independent organizations do not have comparable data and are also excluded from the analysis.

As we state previously, much of what had been written about MFI productivity is without the benefit of empirical support. This problem is a largely a consequence of the limited availability of MFI data. Using high-quality MFI data, we specify and estimate several translog cost functions in order to empirically examine several hypotheses about MFI operations.

\section{The Model}

The translog (transcendental logarithmic) form is used for all the cost estimations. While there are limitations to the translog form, it has a long history of use in this area; for example see Ferrier and Lovell (1990), Altunbas and Molyneaux (1996), and DeYoung and Hasan (1998).

The translog functional form is

$$
\begin{aligned}
& \ln C=\alpha_{0}+\sum \alpha_{j} \ln q_{j}+\sum \beta_{k} \ln p_{k}+(1 / 2) \sum \sum \alpha_{i j} \ln q_{i} \ln q_{j} \\
& +(1 / 2) \sum \sum \beta_{l k} \ln p_{l} \ln p_{k}+\sum \sum \delta_{j k} \ln q_{j} \ln p_{k},
\end{aligned}
$$

where $\mathrm{C}$ is total cost, q's are output levels, p's are input prices, and the $\forall$ 's, $\exists$ 's, and *'s are parameters to be estimated. Homogeneity in input prices requires $\mathrm{E} \exists_{\mathrm{k}}=1, \mathrm{E} \exists_{\mathrm{lk}}=\mathrm{E} \exists_{\mathrm{kl}}=0$ over 1 and $\mathrm{k}$, and $\mathrm{E}_{\mathrm{jk}}=0$ for any $\mathrm{q}_{\mathrm{j}}$. These restrictions are imposed in the estimation by normalizing (dividing) all input prices and total cost by the price of capital (PCAP). Also, data are meanscaled (divided by their means) in order to facilitate calculation of scale economies. In order to improve efficiency of the estimation, we also estimate the cost share equations 


$$
s_{k}=\beta_{k}+\beta_{l k} \ln p_{k}+\cdots+\beta_{l m} \ln p_{m},
$$

with cross equation parameter constraints imposed. The translog cost function, along with the share equations, is estimated using the seemingly unrelated regressions (SUR) method.

\section{Data}

Lack of high quality data has been the major obstacle to studying MFI productivity. The microfinance industry has become more transparent recently as a result of increased competition among MFIs for donations, subsidies, and loans because donors have become more selective of the projects they fund. As a consequence, industry-wide data have become available only recently. An important advantage of the data used here is that these are high-quality data. Simply using financial statements from various MFIs makes comparisons problematic because many MFIs are non-regulated and organizationally diverse. Their financial statements might not include all subsidies and might not be inflation adjusted. Auditing of financial statements is not required of all organizational types. Moreover, differences in cross-country accounting standards complicate the comparison of financial statements across countries.

To correct for such problems, the Micro Banking Bulletin (MBB) has developed standards that facilitate comparisons of MFI financial statements across countries. Individual MFIs from across the world submit their financial data which is checked and corrected by the MBB staff or a regional partner. In the case of Eastern Europe and Central Asia, MFI data is checked and corrected by the Microfinance Center for Central and Eastern Europe and the Newly Independent States (Microfinance Center for CEE and NIS). Staff members of the Microfinance Center CEE and NIS carefully examine each individual financial statement, performing numerous adjustments and checks, and, when necessary, engage in follow-up data collection to ensure that data across MFIs is comparable.

The data used in the study have been provided by the Microfinance Center for CEE and NIS. The data set contains high quality financial information on MFIs operating in Eastern Europe and Central Asia in for the years 1999 to 2004. As Table 1 indicates, the largest numbers of observations in the sample come from Bosnia and Herzegovina (43), Russia (20), and Georgia (18).

Our selection and specification of regression variables generally follows LeCompte and Smith (1990) and Caudill, Ford and Gropper (1995). We explore both the "intermediation 
approach" and the "production approach" to modeling costs. In addition, we combine production and intermediation in to a third approach.

All financial variables are denominated in \$US and adjusted for country-specific inflation. Loans are measured alternately as the number of loans and the dollar volume of loans, depending upon whether the intermediation or production approach is used. Many of the input prices faced by MFIs in the sample are subsidized. We use the subsidized input prices in our cost function because these are the input prices faced by the MFI managers.

In this study we consider as many as two outputs - number of loans and volume of loans, and three inputs: labor, physical capital and financial capital. In addition, other variables believed to be related to MFI costs are also explored. A discussion of the construction of each of the variables used in this study follows.

Labor. The price of labor is calculated as actual personnel expense (unadjusted for inkind subsidies such as salary of senior manager paid in by TA or technical assistance money), divided by the number of employees.

Physical Capital. The price of physical capital is calculated as actual operating expense (unadjusted for in-kind subsidy such as free rent or TA paid fixed capital related expense) minus actual personnel expense divided by the net fixed assets (that is, fixed assets net of accumulated depreciation and adjusted for inflation to account for appreciation of the physical assets).

Financial Capital. The price of financial capital is actual expense on financial capital divided by the stock of financial capital. Financial expense is calculated as the sum of interest and fees on borrowing, net of inflation adjustment expense (calculated as the difference between inflation adjustment expense due to inflation eroding the portfolio and inflation revenue resulting from the increased value of fixed assets) plus other financial expense, which includes exchange rate related expense. We believe exchange rate expense should be included in financial capital because many MFIs obtain loans in hard currency (USD or Euro) but extend loans in local currency and thus face substantial exchange rate risk.

Output. Output is defined two ways in our estimations. Our first measure (NLoans) is actually the number of borrowers. Our data on MFIs contain number of borrowers but not number of loans. Given the typical MFI clientele, it is unlikely that individuals have more than one loan so we do expect a close correspondence between the two. An alternative measure of 
output, VLoans, or the volume of loans is also used in this study. VLoan is defined to be an MFI's loan portfolio net of accumulated loan loss reserves.

Total Cost. Total cost is the sum of input quantities times input prices- the sum of financial expense, adjusted for inflation but not for subsidies, plus actual operating expense.

Estimation of the statistical cost function provides a solid theoretical framework in which to evaluate a variety of factors related to MFI performance. To do so we incorporate several exogenous variables directly into the cost function. We include Age, Pwomen, Group, and several subsidy measures. A brief discussion of each follows.

Age. We include the age of the institution. We expect that learning occurs over the life of the MFI as managers gain experience in that institution and environment. We expect older MFIs to be more efficient producers, such that costs are lower for a given quantity of output.

Pwomen. We include the percentage of loans made to women. There are some findings that indicate that loans to women may be less expensive because women have better repayment rates (Khandker, Khalily, and Kahn, 1995; Hulme 1991, Gobbons and Kasim, 1991). These results come from MFIs in non ECA regions so the precise effect for MFIs in ECA remains an empirical question.

Group. We also examine the effect of the practice of making group loans by the MFI. We define this variable to be equal to one if the MFI made loans to either solidarity groups or village groups. We do not have prior expectations about he sign of this variable because although evidence from non ECA regions suggests that group lending has lower costs, researchers have suggested that innovative individual lending may work as well and be even less costly in the ECA region (Gomez and Santor, 2003; Armendariz de Aghion and Morduch, 2000). Indeed, MFIs in the region have come up with some innovative individual lending practices. For example, in Albania tangible assets with negligible resale value but high private value are effectively used as collateral. In Russia, a visit to the home is as important as look at the financial statements to ensure better screening. In rural Albania, elements of peer screening are introduced in individual lending because villagers must obtain a loan guarantee and a character evaluation by a local village credit committee in order to get a loan.

Subsidy. Our constructed subsidy variable is the sum of two components. The first component accounts for in-kind payments that subsidize costs of labor and physical capital, and is calculated as the difference between adjusted and unadjusted operating expense. The second 
component is the cost of subsidized financial capital calculated as the deposit rate times the average equity, which is the sum of beginning of the year and end of year equity (which includes current year direct subsidies) divided by two. We expect that MFIs with subsidies and thus softer budget constraints will have higher costs.

Sub/NLoan and Sub/VLoan. These are alternative constructed measures of subsidy. $\mathrm{Sub} /$ NLoan is the subsidy per loan and Sub/VLoan is the subsidy per dollar of loans. For the reasons discussed previously, we expect these measures to be positively related to costs.

Subsidy Dependence Index (SDI). The subsidy dependence index is another measure of subsidy that is widely used in the development literature. The SDI, developed by Yaron (1992), is calculated as subsidy divided by revenue from lending, where subsidy is the average cost of capital calculated as the deposit rate times the beginning-of-the-year equity (the sum of paid in capital, donated equity and retained earnings in years prior to the current year) plus the deposit rate times one-half of the additions to equity in the current year. From this amount the value of net income after taxes but before donations is excluded because this is the revenue generated in the current year. Net income unadjusted for inflation is used to construct the SDI. This index is narrowly defined to answer the question by how much a lender must increase its revenues in order to cover its costs if the lender had no access to subsidized resources.

The variable definitions, means, and standard deviations of all variables used in our analyses are given in Table 2. Our original data set contained 171 observations, but some observations were deleted due to missing or unreliable values. In particular, in the final analysis we include only MFIs with positive values of TC, NLoan, VLoan, $\mathrm{P}_{\mathrm{L}}, \mathrm{P}_{\mathrm{K}}$, and $\mathrm{P}_{\mathrm{CAP}}$. Ultimately, our regression results are based on a sample of 155 observations.

\section{Estimation Results}

Initially, we considered estimating a cost function with three outputs: loans, short and long term financial assets, and deposits. We elected not to pursue this specification because few of the ECA MFIs are involved, to a significant degree, in anything other than loans.

Several models are estimated to uncover aspects of MFI operations. These estimation results are contained in Tables 3, 4, and 5. Table 3 presents the SUR estimation results using the number of loans (NLoan) as output. Three models are estimated including different subsidy measures. Column 2 of Table 3 presents the estimation results including our calculated subsidy 
variable. The model exhibits an excellent fit. The system-weighted $\mathrm{R}^{2}$ is 0.81 and thirteen of the fourteen regression coefficients are statistically significant at the $\alpha=.10$ level or better. The signs and magnitudes of the coefficients of NLoan, $\mathrm{P}_{\mathrm{L}}$, and $\mathrm{P}_{\mathrm{K}}$ are all in accord with theory. The coefficient of NLoan is the output elasticity. The value of 0.67 is consistent with the average MFI operating under conditions of increasing returns to scale. However, this result must be interpreted with caution because some MFIs do produce other outputs.

Our main interest is in the signs and magnitudes of the added variables: Age, Pwomen, Group, and Subsidy. Coefficients of all four of these variables are statistically significant at the $\alpha=.10$ level or better. The coefficient of age indicates that costs rise over time as the MFI continues to operate. This may occur due to rent-seeking behavior of MFI managers or, possibly, an increase in the size of the loans being offered. This issue is examined later with the estimation of some additional specifications of output. The coefficient of Pwomen indicates that costs fall as the percentage of loans made to women increases. This finding is consistent with assertions in the development literature. The coefficient of the Group variable indicates that those MFIs offering group loans have lower costs. This finding is also consistent with assertions in the development literature. The positive coefficient of subsidy indicates that larger subsidies are associated with higher costs. This result is consistent with our expectations about inefficiencies created by the presence of subsidies.

Column three of Table 3 presents the SUR estimation results from a similar cost model with the only change being that the Subsidy measure replaced by Sub/NLoan, or subsidy per loan. The results are very similar to those discussed above for the model in column two. The coefficient of the new variable, subsidy per loan, is positive and significant indicating, again, that subsidies are associated with increased costs.

In our final estimation results using the production approach, the subsidy dependence index, SDI, is our measure of subsidy. These SUR estimation results are included in column four of Table 3. The system-weighted $\mathrm{R}^{2}$ is 0.81 and eleven of the fourteen regression coefficients are statistically significant at the $\alpha=.10$ level or better. The output elasticity is estimated to be 0.75 .

The signs and magnitudes of the coefficients of NLoans, $\mathrm{P}_{\mathrm{L}}$, and $\mathrm{P}_{\mathrm{K}}$ are, again, all in accord with theory. However, only two coefficients of the extra variables, Age and Pwomen, are significantly differently from zero. The coefficient of age indicates, again, that costs rise with 
age. The coefficient of Pwomen is negative and significant indicating that making a higher percentage of loans to women reduces costs. The measure of subsidy in this formulation, SDI, is not significantly different from zero.

In order to more fully examine the effects of Age, Pwomen, Group, and Subsidy on MFI costs, we re-estimated the models using the intermediation approach where loans are measured not as the number of loans but as the volume of loans. This approach is probably not as representative of MFI goals and operations as the production approach, but it is in line with many studies of financial institutions. We again use the SUR estimation method and estimate the model three times including different measures of subsidy.

Column two of Table 4 presents the estimation results including our calculated subsidy variable. The system-weighted $\mathrm{R}^{2}$ is 0.86 which is somewhat higher than with the production model. This is expected because the volume of loans is more consistent with the balance sheet approach to the calculation of the other variables in the cost function. Eleven of the fourteen regression coefficients are statistically significantly different from zero at the $\alpha=.10$ level or better and the signs and magnitudes of the coefficients of VLoans, $\mathrm{P}_{\mathrm{L}}$, and $\mathrm{P}_{\mathrm{K}}$ are all in accord with theory. The output elasticity is estimated to equal 0.76 which is, again, consistent with increasing returns to scale. As before, this result is to be interpreted with caution due to the omitted outputs produced by some of the MFIs.

Again, our main interest is in the signs and magnitudes of the added variables: Age, Pwomen, Group, and Subsidy. Coefficients of all four of these variables are statistically significant at the $\alpha=.10$ level or better, however three signs have changed from our production version of the model. Only the coefficient of subsidy is unchanged. The negative coefficient on the age variable is consistent with learning over time and the coefficient of subsidy again indicates that subsidies are associated with inefficiency. However, in this formulation of the cost function the coefficients of Group and Pwomen are positive and statistically significant. The coefficient of Pwomen indicates that costs rise as the percentage of loans made to women increases and the coefficient of Group indicates that making group loans increases costs. Although these findings contradict our earlier results from the production model, they do make sense. Output is now measured as dollar volume of loans. As the loans to women and groups are typically small, for any volume of loans, a greater percentage of loans of this type is likely to increase costs. 
In this formulation the coefficients of Age and Subsidy indicate a tradeoff. The results indicate that one year of operating experience equals about $\$ 75,000$ in subsidy or more when the loan volume is used as the output measure.

Column three of Table 4 presents the SUR estimation results from a similar model with the only change being that the Subsidy variable is replaced by Sub/VLoan, or subsidy per dollar of loans. The system-weighted $\mathrm{R}^{2}$ is 0.86 and ten of the fourteen regression coefficients are statistically significant at the $\alpha=.10$ level or better. The output elasticity is estimated to equal 0.83 and is consistent with increasing returns to scale, subject to the caveat discussed.

The signs and magnitudes of the coefficients of NLoans, $\mathrm{P}_{\mathrm{L}}$, and $\mathrm{P}_{\mathrm{K}}$ are, again, all in accord with theory. The results for the extra variables are also similar to our previous results. The main difference is that the coefficient of Age is no longer statistically significant but retains the negative sign. The coefficients of Pwomen, Group, and Sub/VLoan are statistically significant at the $\alpha=.10$ level or better. As before the coefficients of Pwomen and Group are positive and significant. The coefficient of the alternative subsidy variable, Sub/VLoan, is also positive and significant indicating that subsidies increase costs.

Column four of Table 4 presents the SUR estimation results from the model with the subsidy dependence index, SDI, included. The system-weighted $\mathrm{R}^{2}$ is 0.86 and ten of the fourteen regression coefficients are statistically significant at the $\alpha=.10$ level or better. The output elasticity is estimated to equal 0.81 which again consistent with increasing returns to scale.

The signs and magnitudes of the coefficients of NLoans, $\mathrm{P}_{\mathrm{L}}$, and $\mathrm{P}_{\mathrm{K}}$ are, again, all in accord with theory. The results for the extra variables are also similar to our previous results. The coefficients of Age, Pwomen, Group, and Sub/VLoan are statistically significant at the $\alpha=.10$ level or better. As before the coefficients of Pwomen and Group are positive and significant. The coefficient of the alternative subsidy variable, Sub/VLoan, is also positive and significant indicating that subsides increase costs. Age is once again found to be negatively related to costs.

As an alternative to the "production' and "intermediation" models, we estimate a third set of regressions in which number of loans and volume of loans are included as output variables. Although this approach is seldom used in the literature on financial institutions, we feel it may help capture some of the characteristics of MFIs and provide better information on the effects of 
Age, Pwomen, Group, and Subsidy variables on MFI operations. We are able to perform hypothesis tests about the inclusion of both production and intermediation variables because both models are nested in the present version. As we estimated models using four different subsidy variables, there are four different F-tests to report for each approach. Testing the null hypothesis that the intermediation-based variables are all equal to zero leads to the following test statistics for the four models estimated in Table 5; $\mathrm{F}_{4,447}=126.38,124.93,127.14$, and 136.02. The Fstatistics for the null hypothesis that all of the production-based variables equal zero are 43.06 , $47.25,43.39$, and 45.56, respectively. In every case the null hypothesis is rejected at the $\alpha=.01$ level or better. Thus, we do find statistical evidence for combining number of loans and volume of loans in the cost function.

Column two of Table 5 presents the estimation results including our calculated subsidy variable and both NLoans and VLoans included as output variables. The system-weighted $\mathrm{R}^{2}$ is 0.90. Fifteen of the eighteen regression coefficients are statistically significant at the $\alpha=.10$ level or better and the signs and magnitudes of the coefficients of NLoans, VLoans, $\mathrm{P}_{\mathrm{L}}$, and $\mathrm{P}_{\mathrm{K}}$ are all in accord with theory. Again, our main interest is in the signs and magnitudes of the added variables: Age, Pwomen, Group, and Subsidy. Only the coefficients of Group and Subsidy are statistically significant at the $\alpha=.10$ level or better. The coefficient of Group indicates that MFIs making group loans have higher than average costs. The coefficient of Age is negative which is consistent with learning over time, but not quite statistically significant $(\mathrm{t}=1.58)$. Once again, the coefficient of subsidy indicates that subsidies increase costs. If our earlier calculation is repeated, with caution due to the low significance on Age, the result is that one year of experience is equal to about $\$ 70,000$ of subsidy.

Column three of Table 5 presents the estimation results including subsidy per loan. The system-weighted $\mathrm{R}^{2}$ is again in 0.90 . Fifteen of the eighteen regression coefficients are statistically significant at the $\alpha=.10$ level or better and the signs and magnitudes of the coefficients of NLoans, VLoans, $\mathrm{P}_{\mathrm{L}}$, and $\mathrm{P}_{\mathrm{K}}$ are all in accord with theory. As before, coefficients of Group and the subsidy variable, Sub_NLoan, are statistically significant at the $\alpha=.10$ level or better. Age is once again negative and does not quite achieve statistical significance.

Column four of Table 5 presents the estimation results including subsidy per loan dollar. The system-weighted $\mathrm{R}^{2}$ is again 0.90. Again, fifteen of the eighteen regression coefficients are statistically significant at the $\alpha=.10$ level or better and the signs and magnitudes of the 
coefficients of NLoans, VLoans, $\mathrm{P}_{\mathrm{L}}$, and $\mathrm{P}_{\mathrm{K}}$ are all in accord with theory. As before, coefficients of Group and the subsidy variable, Sub_VLoan are statistically significant at the $\alpha=.10$ level or better.

Column five of Table 5 presents the estimation results including the subsidy dependence index. The system-weighted $\mathrm{R}^{2}$ is again 0.90. Again, fifteen of the eighteen regression coefficients are statistically significant at the $\alpha=.10$ level or better and the signs and magnitudes of the coefficients of NLoans, VLoans, $\mathrm{P}_{\mathrm{L}}$, and $\mathrm{P}_{\mathrm{K}}$ are all in accord with theory. As before, coefficients of Group and the subsidy variable, SDI, are statistically significant at the $\alpha=.10$ level or better. Age is again negative but not statistically significant.

When considering these results as a whole some facts about MFI operations appear clear. The first thing to note is that the mere presence of subsidies is associated with increased costs. That is clear from all output configurations and all measures of subsidy. Second, we find evidence to support the notion that MFIs become more efficient over time when number of loans is the measure of output. We also find that the cost of providing group loans and loans to women is lower and that MFIs heavily engaged in these activities have lower costs.

\section{Conclusions}

Although there are literally hundreds of studies examining bank efficiency issues, our study is the first to examine similar issues in microfinance institutions. We examine microfinance institutions in Eastern Europe and Central Asia using 1999-2004 data.

We estimate three models, each based on different measures of output. Our first formulation uses the number of loans as an output measure and the second formulation uses volume of loans as an output measure. Our final formulation includes both number and volume of loans as outputs. Our most consistent finding is that the presence of subsides increases MFI costs. This result is consistent across all three output specification and across several measures of subsidy. Our other findings vary depending on the particular output measure used. When output is measured as the number of loans, we find that MFIs become more efficient over time. In this formulation of the cost function we also find those MFIs involved in the provision of group loans and loans to women have lower costs. When output is measured as volume of loans, this last finding is reversed. Those MFIs involved in the provision of group loans and loans to women have higher than average costs. 
The need to achieve an outreach mission distinguishes microfinance institutions from other financial intermediaries. MFIs that attempt to reach as many clients as possible are able to do that at lower costs by offering loans to women and using group lending. Banks and other traditional financial firms, therefore, may not be able to compete well with MFIs in achieving such objectives. However, if the goal is to provide access to substantial amount of capital to the entrepreneurial poor, that is, provide access to larger loans in a cost-effective manner, more traditional lending methodologies may be better suited.

MFIs have a role to play in extending credit to those who have traditionally been excluded from formal financial markets. The efficiency with which they perform that role is important in the short term, as they attempt to reach the greatest number of clients, and for the long term growth and development of the formal financial markets and economies in these regions. While MFIs have typically been established with subsidies, some of the evidence found here suggests that they can become more cost efficient over time, and survive without subsidies. Whether MFIs assume a more important role in the longer term financial structure in the ECA region as these countries develop is an interesting and important question. 
TABLE 1

Geographic Distribution of Sample of Microfinance Institutions

\begin{tabular}{|l|l|}
\hline Country & Number of Observations \\
\hline Albania & 9 \\
\hline Armenia & 9 \\
\hline Azerbaijan & 7 \\
\hline Bosnia and Herzegovina & 43 \\
\hline Bulgaria & 6 \\
\hline Croatia (Hrvatska) & 7 \\
\hline Georgia & 18 \\
\hline Kazakhstan & 4 \\
\hline Kosovo & 6 \\
\hline Kyrgyzstan & 8 \\
\hline Macedonia & 1 \\
\hline Moldova & 1 \\
\hline Mongolia & 6 \\
\hline Montenegro & 3 \\
\hline Poland & 1 \\
\hline Romania & 10 \\
\hline Russia & 20 \\
\hline Tajikistan & 3 \\
\hline Ukraine & 3 \\
\hline Uzbekistan & 2 \\
\hline Yugoslavia & 4 \\
\hline & \\
\hline
\end{tabular}


TABLE 2

Variable Definitions and Summary Statistics

\begin{tabular}{|l|l|}
\hline Variable & $\begin{array}{l}\text { Means } \\
\text { (Standard deviations) }\end{array}$ \\
\hline TC (\$US) & $\mathbf{1 , 1 2 2 , 8 2 7}$ \\
(Total Cost) & $\mathbf{( 1 0 0 0 6 4 5 )}$ \\
\hline $\begin{array}{l}\text { NLoan } \\
\text { (The number of loans) }\end{array}$ & $\mathbf{5 4 6 9 . 7}$ \\
\hline VLoan (\$US) & $\mathbf{( 5 9 7 1 )}$ \\
(The volume of loans) & $\mathbf{4 , 8 8 2 , 3 0 1}$ \\
\hline $\mathbf{P}_{\mathbf{L}}$ & $\mathbf{( 5 8 2 1 8 0 4 )}$ \\
\hline $\mathbf{P}_{\mathbf{K}}$ & $\mathbf{8 7 9 2 . 0 4}$ \\
& $\mathbf{( 5 3 4 7 . 1 1 )}$ \\
\hline $\mathbf{P}_{\text {CAP }}$ & $\mathbf{4 . 7 2 4}$ \\
& $\mathbf{( 9 . 8 4 )}$ \\
\hline Pwomen & $\mathbf{0 . 0 7 1}$ \\
(Proportion of loans made to women) & $\mathbf{( 0 . 0 9 )}$ \\
\hline $\begin{array}{l}\text { Group } \\
\text { (Dummy variable indicating that the MFI }\end{array}$ & $\mathbf{0 . 6 0 5}$ \\
makes loans made to either groups or & $\mathbf{( 0 . 2 6 )}$ \\
villages) & $\mathbf{0 . 0 7 7}$ \\
\hline $\begin{array}{l}\text { Subsidy } \\
\text { (The subsidies given to the MFI in 1000s } \\
\text { of dollars) }\end{array}$ & $\mathbf{( 2 0 1 . 8 7 )}$ \\
\hline $\begin{array}{l}\text { SDI } \\
\text { (Subsidy dependence index) }\end{array}$ & \\
\hline
\end{tabular}


TABLE 3

SUR Estimation Results-Production Approach

\begin{tabular}{|c|c|c|c|}
\hline Variable & Model 1 & Model 2 & Model 3 \\
\hline Intercept & $\begin{array}{l}-0.462 \\
(3.40) \\
\end{array}$ & $\begin{array}{l}-0.354 \\
(2.91) \\
\end{array}$ & $\begin{array}{l}-0.261 \\
(2.05) \\
\end{array}$ \\
\hline NLoan & $\begin{array}{l}0.666 \\
(13.4)\end{array}$ & $\begin{array}{l}0.781 \\
(17.56)\end{array}$ & $\begin{array}{l}0.750 \\
(16.04)\end{array}$ \\
\hline $\mathbf{P}_{\mathbf{L}}$ & $\begin{array}{l}0.437 \\
(49.84)\end{array}$ & $\begin{array}{l}0.438 \\
(49.89)\end{array}$ & $\begin{array}{l}0.436 \\
(49.59)\end{array}$ \\
\hline $\mathbf{P}_{\mathbf{K}}$ & $\begin{array}{l}0.326 \\
(37.12)\end{array}$ & $\begin{array}{l}0.325 \\
(37.09)\end{array}$ & $\begin{array}{l}0.329 \\
(37.38)\end{array}$ \\
\hline NLoan*NLoan & $\begin{array}{l}0.114 \\
(3.94) \\
\end{array}$ & $\begin{array}{l}0.112 \\
(4.01) \\
\end{array}$ & $\begin{array}{l}0.141 \\
(4.35) \\
\end{array}$ \\
\hline $\mathbf{P}_{\mathbf{L}} * \mathbf{P}_{\mathbf{L}}$ & $\begin{array}{l}0.071 \\
(13.24)\end{array}$ & $\begin{array}{l}0.073 \\
(13.68)\end{array}$ & $\begin{array}{l}0.073 \\
(14.02)\end{array}$ \\
\hline $\mathbf{P}_{\mathbf{K}} * \mathbf{P}_{\mathrm{K}}$ & $\begin{array}{l}0.060 \\
(11.96)\end{array}$ & $\begin{array}{l}0.061 \\
(12.04)\end{array}$ & $\begin{array}{l}0.062 \\
(12.65)\end{array}$ \\
\hline $\mathbf{P}_{\mathrm{L}} * \mathbf{P}_{\mathrm{K}}$ & $\begin{array}{l}-0.026 \\
(-6.68)\end{array}$ & $\begin{array}{l}-0.027 \\
(6.91) \\
\end{array}$ & $\begin{array}{l}-0.028 \\
(7.40) \\
\end{array}$ \\
\hline $\mathbf{P}_{\mathrm{L}} *$ NLoan & $\begin{array}{l}0.021 \\
(3.93) \\
\end{array}$ & $\begin{array}{l}0.021 \\
(4.03) \\
\end{array}$ & $\begin{array}{l}0.021 \\
(3.97) \\
\end{array}$ \\
\hline $\mathbf{P}_{\mathbf{K}} *$ NLoan & $\begin{array}{l}-0.006 \\
(1.10) \\
\end{array}$ & $\begin{array}{l}-0.006 \\
(1.03) \\
\end{array}$ & $\begin{array}{l}-0.006 \\
(1.05) \\
\end{array}$ \\
\hline Age & $\begin{array}{l}0.028 \\
(1.77) \\
\end{array}$ & $\begin{array}{l}0.026 \\
(1.72) \\
\end{array}$ & $\begin{array}{l}0.035 \\
(2.18) \\
\end{array}$ \\
\hline Pwomen & $\begin{array}{l}-0.458 \\
(3.49) \\
\end{array}$ & $\begin{array}{l}-0.122 \\
(4.06) \\
\end{array}$ & $\begin{array}{l}-0.597 \\
(4.74) \\
\end{array}$ \\
\hline Group & $\begin{array}{l}-0.229 \\
(1.93) \\
\end{array}$ & $\begin{array}{l}-0.209 \\
(1.81)\end{array}$ & $\begin{array}{l}-0.197 \\
(1.62)\end{array}$ \\
\hline Subsidy & $\begin{array}{l}0.001 \\
(3.80) \\
\end{array}$ & ----- & ----- \\
\hline Sub/Nloan & ----- & $\begin{array}{l}0.002 \\
(5.51)\end{array}$ & ----- \\
\hline SDI & ----- & ----- & $\begin{array}{l}0.023 \\
(0.31)\end{array}$ \\
\hline $\begin{array}{l}\text { System-weighted } \\
\mathrm{R}^{2}\end{array}$ & 0.81 & 0.82 & 0.81 \\
\hline
\end{tabular}

*Numbers in parentheses are absolute values of t-ratios. 
TABLE 4

SUR Estimation Results-Intermediation Approach

\begin{tabular}{|c|c|c|c|}
\hline Variable & Model 1 & Model 2 & Model 3 \\
\hline Intercept & $\begin{array}{l}0.144 \\
(1.25)\end{array}$ & $\begin{array}{l}0.218 \\
(2.10)\end{array}$ & $\begin{array}{l}0.299 \\
(2.93)\end{array}$ \\
\hline VLoan & $\begin{array}{l}0.758 \\
(14.09)\end{array}$ & $\begin{array}{l}0.826 \\
(17.01)\end{array}$ & $\begin{array}{l}0.811 \\
(16.99)\end{array}$ \\
\hline $\mathbf{P}_{\mathbf{L}}$ & $\begin{array}{l}0.379 \\
(23.38) \\
\end{array}$ & $\begin{array}{l}0.377 \\
(28.20)\end{array}$ & $\begin{array}{l}0.378 \\
(28.47) \\
\end{array}$ \\
\hline $\mathbf{P}_{\mathbf{K}}$ & $\begin{array}{l}0.314 \\
(25.16)\end{array}$ & $\begin{array}{l}0.315 \\
(25.21)\end{array}$ & $\begin{array}{l}0.315 \\
(25.33)\end{array}$ \\
\hline VLoan*VLoan & $\begin{array}{l}-0.001 \\
(0.05)\end{array}$ & $\begin{array}{l}0.010 \\
(0.44)\end{array}$ & $\begin{array}{l}0.002 \\
(0.07)\end{array}$ \\
\hline $\mathbf{P}_{\mathrm{L}} * \mathbf{P}_{\mathrm{L}}$ & $\begin{array}{l}0.068 \\
(10.50)\end{array}$ & $\begin{array}{l}0.068 \\
(10.37)\end{array}$ & $\begin{array}{l}0.070 \\
(10.87)\end{array}$ \\
\hline $\mathbf{P}_{\mathrm{K}} * \mathbf{P}_{\mathrm{K}}$ & $\begin{array}{l}0.048 \\
(9.37) \\
\end{array}$ & $\begin{array}{l}0.047 \\
(9.14) \\
\end{array}$ & $\begin{array}{l}0.048 \\
(9.35) \\
\end{array}$ \\
\hline $\mathbf{P}_{\mathrm{L}} * \mathbf{P}_{\mathrm{K}}$ & $\begin{array}{l}0.007 \\
(1.67)\end{array}$ & $\begin{array}{l}0.007 \\
(1.55)\end{array}$ & $\begin{array}{l}0.008 \\
(1.74)\end{array}$ \\
\hline $\mathbf{P}_{\mathrm{L}} *$ VLoan & $\begin{array}{l}-0.028 \\
(4.19)\end{array}$ & $\begin{array}{l}-0.029 \\
(4.25)\end{array}$ & $\begin{array}{l}-0.029 \\
(-4.29)\end{array}$ \\
\hline $\mathbf{P}_{\mathrm{K}} *$ VLoan & $\begin{array}{l}-0.004 \\
(0.59) \\
\end{array}$ & $\begin{array}{l}-0.003 \\
(0.41)\end{array}$ & $\begin{array}{l}-0.003 \\
(-0.54)\end{array}$ \\
\hline Age & $\begin{array}{l}-0.024 \\
(1.92)\end{array}$ & $\begin{array}{l}-0.020 \\
(1.60)\end{array}$ & $\begin{array}{l}-0.024 \\
(1.96)\end{array}$ \\
\hline Pwomen & $\begin{array}{l}0.321 \\
(3.38)\end{array}$ & $\begin{array}{l}0.305 \\
(3.16)\end{array}$ & $\begin{array}{l}0.285 \\
(3.03)\end{array}$ \\
\hline Group & $\begin{array}{l}0.171 \\
(1.85) \\
\end{array}$ & $\begin{array}{l}0.169 \\
(1.78)\end{array}$ & $\begin{array}{l}0.193 \\
(2.09) \\
\end{array}$ \\
\hline Subsidy & $\begin{array}{l}0.000 \\
(2.25) \\
\end{array}$ & ----- & ----- \\
\hline Sub/Vloan & ----- & $\begin{array}{l}1.148 \\
(2.29) \\
\end{array}$ & ----- \\
\hline SDI & ----- & ----- & $\begin{array}{l}0.087 \\
(1.66) \\
\end{array}$ \\
\hline $\begin{array}{l}\text { System-weighted } \\
\mathbf{R}^{2}\end{array}$ & 0.86 & 0.86 & 0.86 \\
\hline
\end{tabular}

*Numbers in parentheses are absolute values of t-ratios. 
TABLE 5

SUR Estimation Results-Combined Approach

\begin{tabular}{|c|c|c|c|c|}
\hline Variable & Model 1 & Model 2 & Model 3 & Model 4 \\
\hline Intercept & $\begin{array}{l}0.179 \\
(1.83)\end{array}$ & $\begin{array}{l}0.223 \\
(2.61)\end{array}$ & $\begin{array}{l}0.234 \\
(2.67)\end{array}$ & $\begin{array}{l}0.305 \\
(3.53) \\
\end{array}$ \\
\hline VLoan & $\begin{array}{l}0.569 \\
(11.07)\end{array}$ & $\begin{array}{l}0.585 \\
(12.08)\end{array}$ & $\begin{array}{l}0.620 \\
(12.31)\end{array}$ & $\begin{array}{l}0.596 \\
(12.19)\end{array}$ \\
\hline NLoan & $\begin{array}{l}0.319 \\
(8.84)\end{array}$ & $\begin{array}{l}0.356 \\
(9.93)\end{array}$ & $\begin{array}{l}0.317 \\
(8.69)\end{array}$ & $\begin{array}{l}0.327 \\
(9.23)\end{array}$ \\
\hline $\mathbf{P}_{\mathrm{L}}$ & $\begin{array}{l}0.339 \\
(29.13)\end{array}$ & $\begin{array}{l}0.338 \\
(29.08)\end{array}$ & $\begin{array}{l}0.338 \\
(28.98)\end{array}$ & $\begin{array}{l}0.340 \\
(29.15)\end{array}$ \\
\hline $\mathbf{P}_{\mathbf{K}}$ & $\begin{array}{l}0.336 \\
(26.37)\end{array}$ & $\begin{array}{l}0.336 \\
(26.46)\end{array}$ & $\begin{array}{l}0.337 \\
(26.47)\end{array}$ & $\begin{array}{l}0.336 \\
(26.39)\end{array}$ \\
\hline VLoan*VLoan & $\begin{array}{l}-0.027 \\
(1.29)\end{array}$ & $\begin{array}{l}-0.016 \\
(0.82)\end{array}$ & $\begin{array}{l}-0.120 \\
(0.98)\end{array}$ & $\begin{array}{l}-0.027 \\
(1.33)\end{array}$ \\
\hline NLoan*NLoan & $\begin{array}{l}0.101 \\
(5.03)\end{array}$ & $\begin{array}{l}0.097 \\
(4.84)\end{array}$ & $\begin{array}{l}0.103 \\
(5.06)\end{array}$ & $\begin{array}{l}0.092 \\
(4.38)\end{array}$ \\
\hline $\mathbf{P}_{\mathrm{L}}{ }^{*} \mathbf{P}_{\mathrm{L}}$ & $\begin{array}{l}0.091 \\
(15.57)\end{array}$ & $\begin{array}{l}0.091 \\
(15.64)\end{array}$ & $\begin{array}{l}0.091 \\
(15.64)\end{array}$ & $\begin{array}{l}0.091 \\
(15.54)\end{array}$ \\
\hline $\mathbf{P}_{\mathrm{K}} * \mathbf{P}_{\mathrm{K}}$ & $\begin{array}{l}0.066 \\
(13.56)\end{array}$ & $\begin{array}{l}0.067 \\
(13.81)\end{array}$ & $\begin{array}{l}0.065 \\
(13.38)\end{array}$ & $\begin{array}{l}0.065 \\
(13.29)\end{array}$ \\
\hline $\mathbf{P}_{\mathbf{L}} * \mathbf{P}_{\mathbf{K}}$ & $\begin{array}{l}-0.017 \\
(4.30)\end{array}$ & $\begin{array}{l}-0.017 \\
(4.39)\end{array}$ & $\begin{array}{l}-0.018 \\
(4.43)\end{array}$ & $\begin{array}{l}-0.017 \\
(4.26)\end{array}$ \\
\hline PL*NLoan & $\begin{array}{l}0.064 \\
(11.21)\end{array}$ & $\begin{array}{l}0.064 \\
(11.25)\end{array}$ & $\begin{array}{l}0.065 \\
(11.31)\end{array}$ & $\begin{array}{l}0.064 \\
(11.17)\end{array}$ \\
\hline Pk*NLoan & $\begin{array}{l}-0.023 \\
(3.49)\end{array}$ & $\begin{array}{l}-0.023 \\
(3.51)\end{array}$ & $\begin{array}{l}-0.024 \\
(3.55)\end{array}$ & $\begin{array}{l}-0.024 \\
(3.52)\end{array}$ \\
\hline$P_{L} *$ VLoan & $\begin{array}{l}-0.082 \\
(10.96)\end{array}$ & $\begin{array}{l}-0.082 \\
(11.03)\end{array}$ & $\begin{array}{l}-0.083 \\
(11.09)\end{array}$ & $\begin{array}{l}-0.081 \\
(10.87)\end{array}$ \\
\hline $\mathbf{P}_{\mathrm{K}} *$ VLoan & $\begin{array}{l}0.024 \\
(3.02)\end{array}$ & $\begin{array}{l}0.025 \\
(3.11)\end{array}$ & $\begin{array}{l}0.026 \\
(3.20)\end{array}$ & $\begin{array}{l}0.025 \\
(3.11)\end{array}$ \\
\hline Age & $\begin{array}{l}-0.016 \\
(1.52)\end{array}$ & $\begin{array}{l}-0.016 \\
(1.58)\end{array}$ & $\begin{array}{l}-0.013 \\
(1.25)\end{array}$ & $\begin{array}{l}-0.015 \\
(1.46)\end{array}$ \\
\hline Pwomen & $\begin{array}{l}0.034 \\
(0.38)\end{array}$ & $\begin{array}{l}0.020 \\
(0.23)\end{array}$ & $\begin{array}{l}0.015 \\
(0.16)\end{array}$ & $\begin{array}{l}-0.007 \\
(0.08)\end{array}$ \\
\hline Group & $\begin{array}{l}0.219 \\
(2.73)\end{array}$ & $\begin{array}{l}0.211 \\
(2.66)\end{array}$ & $\begin{array}{l}0.215 \\
(2.65)\end{array}$ & $\begin{array}{l}0.220 \\
(2.74)\end{array}$ \\
\hline Subsidy & $\begin{array}{l}0.000 \\
(1.89)\end{array}$ & ---- & ---- & ---- \\
\hline Sub/Vloan & ----- & $\begin{array}{l}0.001 \\
(2.71)\end{array}$ & ----- & ----- \\
\hline Sub/Nloan & ---- & ---- & $\begin{array}{l}0.941 \\
(2.23)\end{array}$ & ---- \\
\hline SDI & ----- & ----- & ----- & $\begin{array}{l}0.121 \\
(2.63)\end{array}$ \\
\hline $\mathbf{R}^{2}$ & 0.90 & 0.90 & 0.90 & 0.90 \\
\hline
\end{tabular}




\section{References}

Altunbas, Y., Gardener, E.P.M., Molyneux, P., and Moore, B. (2001) Efficiency in European Banking, European Economic Review, 45, 1931-1955.

Altunbas, Y., and Molyneux, P. (1996) Economies of Scale and Scope in European Banking, Applied Financial Economics, 6, 367-375.

Armendariz de Aghion B., and Morduch, J. (2000). Microfinance Beyond Group Lending. Economics of Transition, 8, 401-420.

Armendariz de Aghion B., and Morduch, J. (2005). Microeconomics of Microfinance. MIT Press.

Armendariz de Aghion, B., and Collier, C. (2000), Peer Group Information in an Adverse Selection Model, The Economic Journal, 110, 632-643.

Barth, J., Caprio, G., and Levine, R. (2004) Bank Regulation and Supervision: What Works Best?" Journal of Financial Intermediation, 13, 205-248.

Benchmarking Microfinance in Eastern Europe and Central Asia: A report from the Microfinance Information eXchange, Available at the Microfinance Center http://www.mfc.org.pl/doc/Publication/ECA_Benchmarking.pdf

Berger, A., Hasan, I., and Klapper, L. (2004). Further Evidence on the Link between Finance and Growth: An International Analysis of Community Banking and Economic Performance, Journal of Financial Services Research 25, 169-202.

Berger, A., Klapper, L., Miller, M., and Udell, G., (2003) Relationship Lending in the Argentine Small Business Credit Market, in Credit Reporting Systems and the International Economy, Cambridge and London MIT Press, 255-270.

Berger, A and Udell, G. (1995). Relationship Lending and Lines of Credit in Small Firm Finance, Journal of Business 68, 351-81.

Berger, A and Udell, G. (2002), Small Business Credit Availability and Relationship Lending: The Importance of Bank Organizational Structure, Economic Journal 112, 32-53.

Bonin, J.P., Hasan, I., and Wachtel P. (2005a) Privatization Matters: Bank Efficiency in Transition Countries, Journal of Banking and Finance 29, 2155-2178.

Bonin, J.P., Hasan, I., and Wachtel P. (2005b). Bank Performance, Efficiency and Ownership in Transition Countries, Journal of Banking and Finance 29, 31-53.

Brau, J., and Woller, G. (2004). Microfinance: A Comprehensive Review of the Existing Literature, The Journal of entrepreneurial Finance and Business Ventures, 9, 1-26. 
Caudill, S.B., Ford, J.M., and Gropper, D.M. (1995). "Frontier Estimation and Firm-specific Inefficiency Measures in the Presence of Heteroscedasticity," Journal of Business and Economic Statistics 13, 105-111.

Conning, J. (1999) "Outreach, Sustainability and Leverage in Monitored and Peer Monitored Lending," Journal of Development Economics, 60, 51-77.

Demirgüç-Kunt, A., Laeven, L. and Levine R. (2004). "Regulations, Market Structure, Institutions, and the Cost of Financial Intermediation," Journal of Money, Credit, and Banking, 36(3), 593-622.

DeYoung, R. and Hasan, I. (1998) The Performance of de Novo Commercial Banks: A Profit Efficiency Approach, Journal of Banking and Finance, 22, 565-587.

Ferrier, G., and Lovell, C. A. K., (1990) Measuring Cost Efficiency in Banking: Econometric and Linear Programming Evidence, Journal of Econometrics, 46, 229-245.

Fries, S. and Taci, A. (2005) Cost Efficiency of Banks in Transition: Evidence from 289 Banks in 15 Post-Communist Countries, Journal of Banking and Finance, 29, 55-81.

Foster, S., Green S., and Pytkowska, J. (2003). The State of Microfinance in CEE and NIS, Washington, D.C.: Consultative Group to Assist the Poor.

Ghatak, M. (1999) “Group Lending, Local Information and Peer Selection,” Journal of Development Economics, 60, 27-50.

Gobbons D., and Kasim, S. (1991), Banking on the Rural Poor, Center for Policy Research, University Sains, Malaysia

Gomez R., and Santor, E. (2003), "Do Peer Members Outperform Individual Members? A Test of Peer Group Lending Using Canadian Micro-Credit Data," Bank of Canada Working Paper, 2003-33.

Gropper, D. M., "An Empirical Investigation of Changes in Scale Economies for Commercial Banking Firms, 1979-1986," Journal of Money, Credit, and Banking, 23, 1991, pp. 718727.

Hartarska, V. (2005). Governance and Performance of Microfinance Organizations in Central and Eastern Europe and the Newly Independent States, World Development," 33, 16271643 .

Hasan, I. and Marton, K. (2003). Development and Efficiency of the Banking Sector in a Transitional Economy: Hungarian Experience, Journal of Banking and Finance, 27, 2249-2271. 
Hulme, D. (1991). “The Malawi Mudzi Fund: Daughter of Grameen," Journal of International Development 3, 427-432.

Khandker, S., Khalily, B., and Kahn, Z. (1995), "Grameen Banks: Performance and Sustainability" World Bank Discussion Paper 306, Washington D.C.

Laffont, J., and Rey, P. (2003), “Collusion and Group Lending with Moral Hazard,” Draft, IDEI Toulouse and University of Southern California.

LeCompte, R.L.B. and Smith, S.D. (1990). Changes in the Cost of Intermediation: The Cost of Savings and Loans, Journal of Finance 45, 1337-1346.

MicroBanking Bulletin, Trend Lines, Issue No. 10, March, 2005.

Microcredit in Transitional Economies, LEED The Programme on Local Economic and Employment Development, Territorial Development Service, Organization for Economic Co-operation and Development, Paris 1996.

Navajas, S., Schreiner, M., Meyer, R., Gonzalez-Vega C., and Rodriguez-Meza J. (2000). Microcredit and the Poorest of the Poor: Theory and Evidence from Bolivia. World Development, 28, 333-46.

Pastor, J. (2002) Credit Risk and Efficiency in the European Banking System, Applied Financial Economics, 12, 895-911.

Pastor, J., Perez, F., and Quesada, J. (1997) Efficiency Analysis in Banking Firms: An International Comparison, European Journal of Operational Research, 98, 396-408.

Perotti, E.C. (1998), "Inertial Credit and Opportunistic Arrears in Transition", European Economic Review, 42, 1703-1725.

Pytkowska, J. August 2004 MFC Spotlight Note 12, Overview of the Microfinance Industry in the ECA Region in 2003.

Rai A. and Sjoststron, T. (2004), "Is Grameen Lending Efficient? Repayment Incentives and Insurance in Village Economies," Review of Economic Studies 71, 217-234.

Stiglitz, J. (1990) "Peer Monitoring and Credit Markets," World Bank Economic Review, 4, 351366.

Yaron, J. (1992) “Assessing Development Financial Institutions: A Public Interest Analysis," World Bank Discussion Paper 174, Washington D.C. 


\section{DAVIDSON INSTITUTE WORKING PAPER SERIES - Most Recent Papers}

The entire Working Paper Series may be downloaded free of charge at: www.wdi.umich.edu

CURRENT AS OF 3/306

\begin{tabular}{|c|c|c|}
\hline Publication & Authors & Date \\
\hline $\begin{array}{l}\text { No. 809: The Cost Structure of Microfinance Institutions in Eastern } \\
\text { Europe and Central Asia }\end{array}$ & $\begin{array}{l}\text { Valentina Hartarska, Steven B. } \\
\text { Caudill and Daniel M. Gropper }\end{array}$ & Jan. 2006 \\
\hline $\begin{array}{l}\text { No. 808: Ethnic Conflict \& Economic Disparity: Serbians \& Albanians } \\
\text { in Kosovo }\end{array}$ & $\begin{array}{l}\text { Sumon Bhaumik, Ira Gang and } \\
\text { Myeong-Su Yun }\end{array}$ & Sept. 2005 \\
\hline No. 807: A Note on Poverty in Kosovo & $\begin{array}{l}\text { Sumon Bhaumik, Ira Gang and } \\
\text { Myeong-Su Yun }\end{array}$ & Dec. 2005 \\
\hline No. 806: Privatization \& State Capacity in Postcommunist Society & $\begin{array}{l}\text { Lawrence King and Patrick } \\
\text { Hamm }\end{array}$ & Dec. 2005 \\
\hline $\begin{array}{l}\text { No. 805: Corporate Governance, Managers' Independence, Exporting \& } \\
\text { Performance in Firms in Transition Economies }\end{array}$ & $\begin{array}{l}\text { Igor Filatotchev, Natalia } \\
\text { Isachenkova and Tomasz } \\
\text { Mickiewicz, }\end{array}$ & Nov. 2005 \\
\hline $\begin{array}{l}\text { No. 804: Financial Deregulation \& Economic Growth in the Czech } \\
\text { Republic, Hungary and Poland }\end{array}$ & Patricia Mc Grath & Nov. 2005 \\
\hline $\begin{array}{l}\text { No. 803: Evaluating the Causal Effect of Foreign Acquisition on } \\
\text { Domestic Performances: The Case of Slovenian Manufacturing Firms }\end{array}$ & Sergio Salis & Jan. 2006 \\
\hline No. 802: Implications of ERM2 for Poland's Monetary Policy & $\begin{array}{l}\text { Lucjan T. Orlowski and Krzysztof } \\
\text { Rybinski }\end{array}$ & Dec. 2005 \\
\hline $\begin{array}{l}\text { No. 801: Original Sin, Good Works, and Property Rights in Russia: } \\
\text { Evidence From a Survey Experiment }\end{array}$ & Timothy Frye & Sept. 2005 \\
\hline $\begin{array}{l}\text { No. 800: Fiscal Reform \& Its Firm-Level Effects in Eastern Europe \& } \\
\text { Central Asia }\end{array}$ & John Anderson & Aug. 2005 \\
\hline $\begin{array}{l}\text { No. 799: Bond Yield Compression in the Countries Converging to the } \\
\text { Euro }\end{array}$ & $\begin{array}{l}\text { Lucjan Orlowski and Kirsten } \\
\text { Lommatzsch }\end{array}$ & Oct. 2005 \\
\hline $\begin{array}{l}\text { No. 798: Contagion Across \& Integration of Central \& Eastern } \\
\text { European Stock Markets: Evidence from Intraday Data }\end{array}$ & Balazs Egert and Evzen Kocenda & Nov. 2005 \\
\hline No. 797: Real Exchange Rate Misalignment: Prelude to Crisis? & David Kemme and Saktinil Roy & Oct. 2005 \\
\hline $\begin{array}{l}\text { No. 796: Balassa-Samuelson Meets South Eastern Europe, the CIS and } \\
\text { Turkey: A Close Encounter of the Third Kind? }\end{array}$ & Balázs Égert & Nov. 2005 \\
\hline $\begin{array}{l}\text { No. 795: A Comparison of Reform-Era Labor Force Participation Rates } \\
\text { of China's Ethnic Minorities and Han Majority }\end{array}$ & $\begin{array}{l}\text { Margaret Maurer-Fazio, James W. } \\
\text { Hughes and Dandan Zhang }\end{array}$ & Oct. 2005 \\
\hline $\begin{array}{l}\text { No. 794: Collective Action and Post-Communist Enterprise: } \\
\text { The Economic Logic of Russia's Business Associations }\end{array}$ & William Pyle & Sept. 2005 \\
\hline $\begin{array}{l}\text { No. 793: Equilibrium Exchange Rates in Transition Economies: } \\
\text { Taking Stock of the Issues }\end{array}$ & Balázs Égert & Oct. 2005 \\
\hline No. 792: Bribery: Who Pays, Who Refuses, What Are The Payoffs? & Jennifer Hunt and Sonia Laszlo & Sept. 2005 \\
\hline $\begin{array}{l}\text { No. 791: Gender Differences In Personality and Earnings: Evidence from } \\
\text { Russia }\end{array}$ & $\begin{array}{l}\text { Susan Linz and Anastasia } \\
\text { Semykina }\end{array}$ & Apr. 2005 \\
\hline No. 790: Why Are Some Public Officials More Corrupt Than Others? & Jennifer Hunt & Sept. 2005 \\
\hline No. 789: Disinflation and Monetary Policy Arrangements in Romania & Daniel Daianu and Ella Kalai & Nov. 2004 \\
\hline $\begin{array}{l}\text { No. 788: Does Economic Uncertainty Affect the Decision to Bear } \\
\text { Children? Evidence from East and West Germany }\end{array}$ & $\begin{array}{l}\text { Sumon Kumar Bhaumik and } \\
\text { Jeffrey B. Nugent }\end{array}$ & Aug. 2005 \\
\hline $\begin{array}{l}\text { No. 787: Economic Reform and Changing Patterns of Labor Force } \\
\text { Participation in Urban and Rural China }\end{array}$ & $\begin{array}{l}\text { Margaret Maurer-Fazio and James } \\
\text { W. Hughes }\end{array}$ & Aug. 2005 \\
\hline $\begin{array}{l}\text { No. 786: The Determinants of Asset Stripping: Theory and Evidence } \\
\text { From the Transition Economies }\end{array}$ & $\begin{array}{l}\text { Nauro F. Campos and Francesco } \\
\text { Giovannoni }\end{array}$ & Aug. 2005 \\
\hline $\begin{array}{l}\text { No. 785: How to Catch Foreign Fish? FDI and Privatization in EU } \\
\text { Accession Countries }\end{array}$ & $\begin{array}{l}\text { Bruno Merlevede and Koen } \\
\text { Schoors }\end{array}$ & Aug. 2005 \\
\hline $\begin{array}{l}\text { No. 784: Does the World Bank have any impact on human development } \\
\text { of the poorest countries? Some preliminary evidence from Africa }\end{array}$ & Sumon Kumar Bhaumik & Aug. 2005 \\
\hline $\begin{array}{l}\text { No. 783: Comparative social capital: Networks of entrepreneurs and } \\
\text { investors in China and Russia }\end{array}$ & Bat Batjargal & July 2005 \\
\hline $\begin{array}{l}\text { No. 782: Exchange Rate Regimes, Foreign Exchange Volatility and } \\
\text { Export Performance in Central and Eastern Europe: Just Another Blur } \\
\text { Project? }\end{array}$ & $\begin{array}{l}\text { Balázs Égert and Amalia Morales- } \\
\text { Zumaquero }\end{array}$ & July 2005 \\
\hline
\end{tabular}

